\title{
Mechanical and Metallurgical Evaluation of Carburized, Conventionally and Intensively Quenched Steels
}

\author{
T. Giordani, T.R. Clarke, C.E.F. Kwietniewski, M.A. Aronov, N.I. Kobasko, and G.E. Totten
}

(Submitted January 25, 2013; published online March 27, 2013)

\begin{abstract}
Steels subjected to carburizing, quenching, and tempering are widely used for components that require hardness and superficial mechanical resistance together with good core toughness. Intensive quenching is a method that includes advantages including crack prevention, increased mechanical resistance, and improvement in fatigue performance when subjected to very fast (intensive) cooling. However, achieving these advantages requires the formation of sufficiently high surface compressive residual stresses and fine grains at the core of steel components. If the cooling rate is sufficiently high after intensive quenching, then low-hardenability, killed plain carbon steels may be used instead of higher-cost, low alloy steels because compressive residual stresses are formed at the surface of steel parts. The objective of this study was to compare between carburized non-killed AISI 1020 steel samples, which were not modified by Al that were subsequently conventionally and also intensively quenched to determine the effect of quenching on achieving the necessary formation of fine grain size. For comparison, carburized AISI 8620 steel test specimens were conventionally quenched. After quenching, all test specimens were characterized by metallurgical and mechanical analyses. The results of this study showed that when the two quenching methods were compared for carburized non-killed AISI 1020 steel, intensive quenching method was found to be superior with respect to mechanical and metallurgical properties. When comparing the different steels, it was found that intensively quenched, non-killed, AISI 1020 steel yielded grain sizes which were three times greater than those obtained with conventionally quenched, carburized AISI 8620 steel. Therefore, the benefits of intensive quenching were negated. These results show that plain carbon steels must be modified by Al to make fine grains if intensively quenched plain-carbon steel is to replace alloyed AISI 8620 steel.
\end{abstract}

Keywords carburizing, fatigue, intensive quenching

\section{Introduction}

AISI 8620 steel is a low-alloy steel commonly used for the manufacture of carburized parts. In this steel, nickel increases toughness, and chromium and molybdenum contribute to increasing the depth of the hardened layer formed by carburizing and to result in increased wear resistance. Non-alloyed AISI 1020 steel which also may be used for carburizing contains the same nominal carbon content and compared with AISI 8620 exhibits poorer hardenability and superior forgeability and weldability.

The gas carburizing process involves heating and holding low-carbon steel at a temperature normally in the range of $1650-1800{ }^{\circ} \mathrm{F}\left(899-982{ }^{\circ} \mathrm{C}\right)$ in a controlled atmosphere which causes additional carbon to diffuse into the steel, typically to approximately $0.70-1.10 \%$ carbon at the surface. However, surface carbon is typically limited to approximately $0.9 \%$ because high carbon contents can result in the formation of

T. Giordani, T.R. Clarke, and C.E.F. Kwietniewski, Department of Metallurgy, Universidade Federal do Rio Grande do Sul, Porto Alegre, Rio Grande do Sul, Brazil; M.A. Aronov and N.I. Kobasko, Akron Steel Treating Company, Akron, OH; and G.E. Totten, Department of Mechanical and Materials Engineering, Portland State University, Portland, OR. Contact e-mail: tiago_jorda@yahoo.com.br. unacceptable amounts of retained austenite and brittle martensite. The total depth of the hardened case of carburized steel is a function of carburizing time and available carbon potential at the surface. After carburizing for the appropriate time, the steel is cooled to $1475-1550{ }^{\circ} \mathrm{F}\left(802-843{ }^{\circ} \mathrm{C}\right)$ and held at temperature to stabilize while maintaining the carbon potential, and then it is direct quenched (boost-diffuse and direct quench) or the steel may be cooled to ambient temperature, reheated to austenitization temperature and quenched (reheat and quench). After quenching, the steel is usually tempered at $300-375^{\circ} \mathrm{F}$ $\left(149-191{ }^{\circ} \mathrm{C}\right)$. Carburized and hardened steel is used when optimum properties are required such as high surface hardness, high case strength and fatigue resistance, and high tensile and impact strength properties. To achieve this, compressive surface residual stress in the hardened case and suitable core properties are required (Ref 1).

Quenching is performed at the conclusion of the carburizing process, and it involves cooling of the austenitized steel in a medium such as water, oil, or brine at a rate sufficient to permit the formation of martensite. However, high cooling rates lead to the possibility of cracking due to formation of excessive thermal and transformation stresses, and volumetric expansion that occurs during martensite transformation.

Among the lesser-known quenching methods is intensive quenching. Kobasko has published a series of articles beginning in 1964 in which he reported that greater than an alloyspecific cooling rate, there is a decreasing probability of cracking as shown in Fig. 1. Intensive quenching involves the utilization of convective cooling at rates sufficiently fast to remove heat from the steel as fast as it can be released which is 


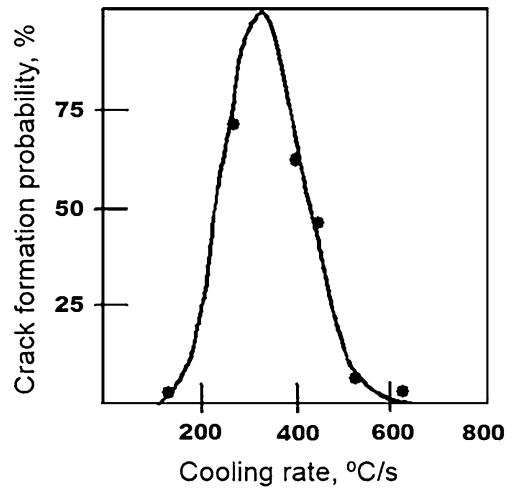

Fig. 1 Relationship between probability of cracking and cooling rate $(\operatorname{Ref} 2,3)$

Table 1 Chemical composition of AISI 1020 and 8620 steel

\begin{tabular}{lcclc}
\hline & Sample, $\%$ & AISI 1020, \% & Sample, \% & AISI 8620, \% \\
\hline $\mathrm{Cr}$ & 0.22 & $0.18-0.23$ & 0.24 & $0.18-0.23$ \\
$\mathrm{Si}$ & 0.15 & $\ldots$ & 0.32 & $0.15-0.35$ \\
$\mathrm{Mn}$ & 0.52 & $0.30-0.60$ & 0.82 & $0.70-0.90$ \\
$\mathrm{P}$ & 0.01 & $0.03 \max$ & 0.017 & $0.03 \max$ \\
$\mathrm{Si}$ & 0.01 & $0.05 \max$ & 0.03 & $0.04 \max$ \\
$\mathrm{Cr}$ & 0.01 & $\ldots$ & 0.49 & $0.40-0.60$ \\
$\mathrm{Mo}$ & 0.05 & $\ldots$ & 0.18 & $0.15-0.25$ \\
$\mathrm{Ni}$ & 0.01 & $\ldots$ & 0.45 & $0.40-0.70$ \\
$\mathrm{Al}$ & 0.003 & $\ldots$ & 0.03 & $\ldots$ \\
$\mathrm{N}$ & 0.0088 & $\ldots$ & 0.0094 & $\ldots$ \\
\hline
\end{tabular}

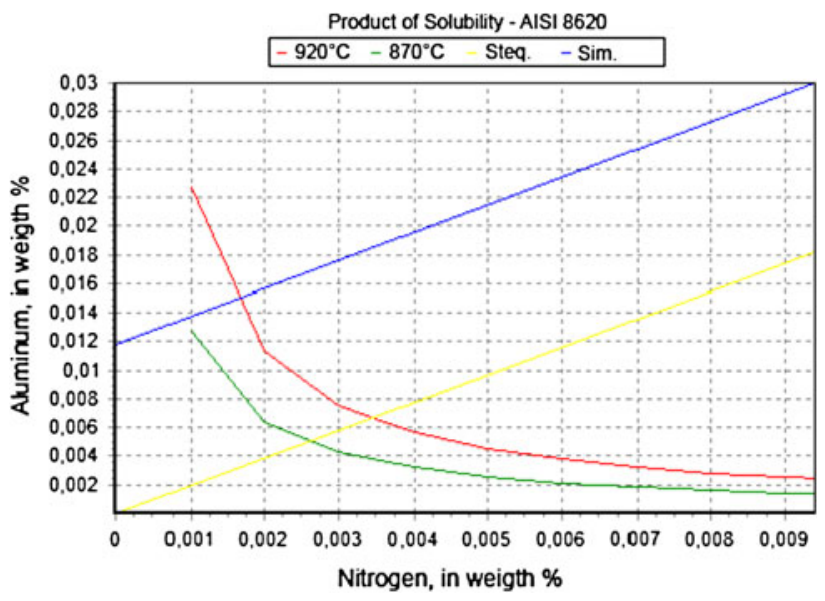

Fig. 2 Plot of aluminum against nitrogen in wt.\%, for different temperatures and compositions in carburized steel AISI 8620 steel

dependent on its thermal conductivity. The intensive quenching process is timed to yield optimal as-quenched martensitic case depths. When conducted properly, intensive quenching is capable of producing optimum compressive stresses and case depths which are typically greater than those achievable by carburizing (Ref 2-5).

The objectives of the study reported here were to

- Evaluate non-killed carbon steel that was not modified by $\mathrm{Al}$ and which typically exhibits large grains after quenching in oil.

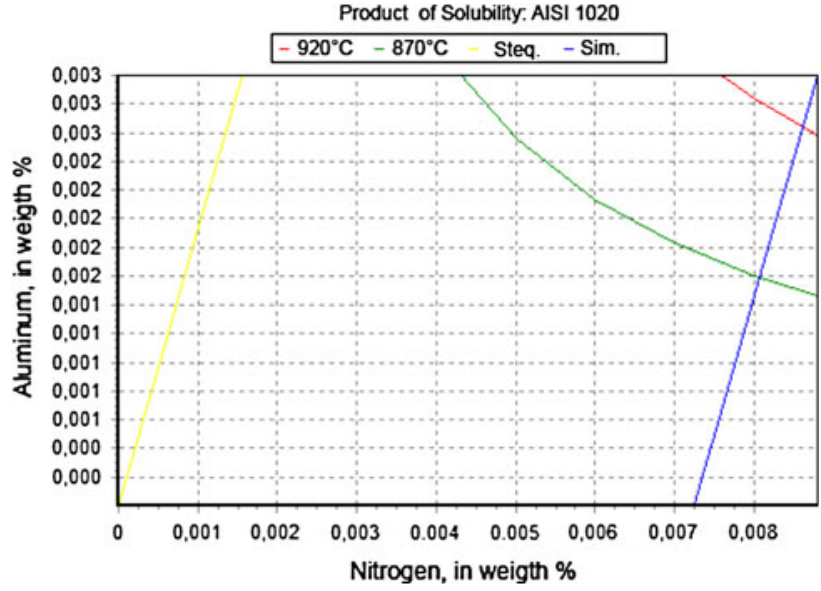

Fig. 3 Plot of aluminum against nitrogen in wt.\%, for different temperatures and compositions in carburized AISI 1020 steel

- Compare a non-killed AISI 1020 that was carburized and intensively quenched with a more costly low-carbon, lowalloy AISI 8620 steel commonly used for carburizing.

- Evaluate the substitution of a more expensive carburized AISI 8620 steel with a less expensive steel subjected to different quenching treatments. In this way, it would be possible to evaluate the benefits of intensive quenching using the same carburized material compared with a carburized and conventionally quenched steel.

\section{Materials and Methods}

Chemical analyses were performed on the as-received steel. The analyses were performed in triplicate using an optical emission spectrometer, model LAVFA18B Spectrolab. The equipment was calibrated according DIN ISO 10012.1.

Two steels were used for this study: AISI 1020, a non-killed low-carbon steel; and a low-alloy, low-carbon AISI 8620 steel. The chemical compositions of both steels are provided in Table 1. Based on the results of chemical composition, a plot showing the product of solubility between elements aluminum and nitrogen was performed for each steel. Figure 2 shows that for the chemical composition of AISI 8620 steel, there is large precipitation of aluminum nitrides at temperatures above carburizing temperatures $\left(920^{\circ} \mathrm{C}\right)$. Figure 3 shows that for the AISI 1020 steel, the precipitation of these nitrides is minimal compared with AISI 8620 shown in Fig. 2.

Standardized microstructural analyses were performed. The as-received bar stock and also the intensively and conventionally treated test specimens used in the present study were cut transversally, embedded, and ground using a series of grinding papers, and then polished with diamond paste. The procedure was performed according to ABNT NBR13284:1995. Chemical etching was performed with Nital $2 \%$ (solution of $2 \%$ of nitric acid dissolved in ethanol). The etching procedure followed ABNT NBR 8108:1983. For photo acquisition, an Olympus BX51M with digital acquisition system was used.

Preparation of the test specimens for grain size determination by ASTM E112-96 (linear interception method) differed only by the etching procedure (Ref 6 ). A mixture of heated $10 \%$ picric acid in water and high surface tension detergent was 

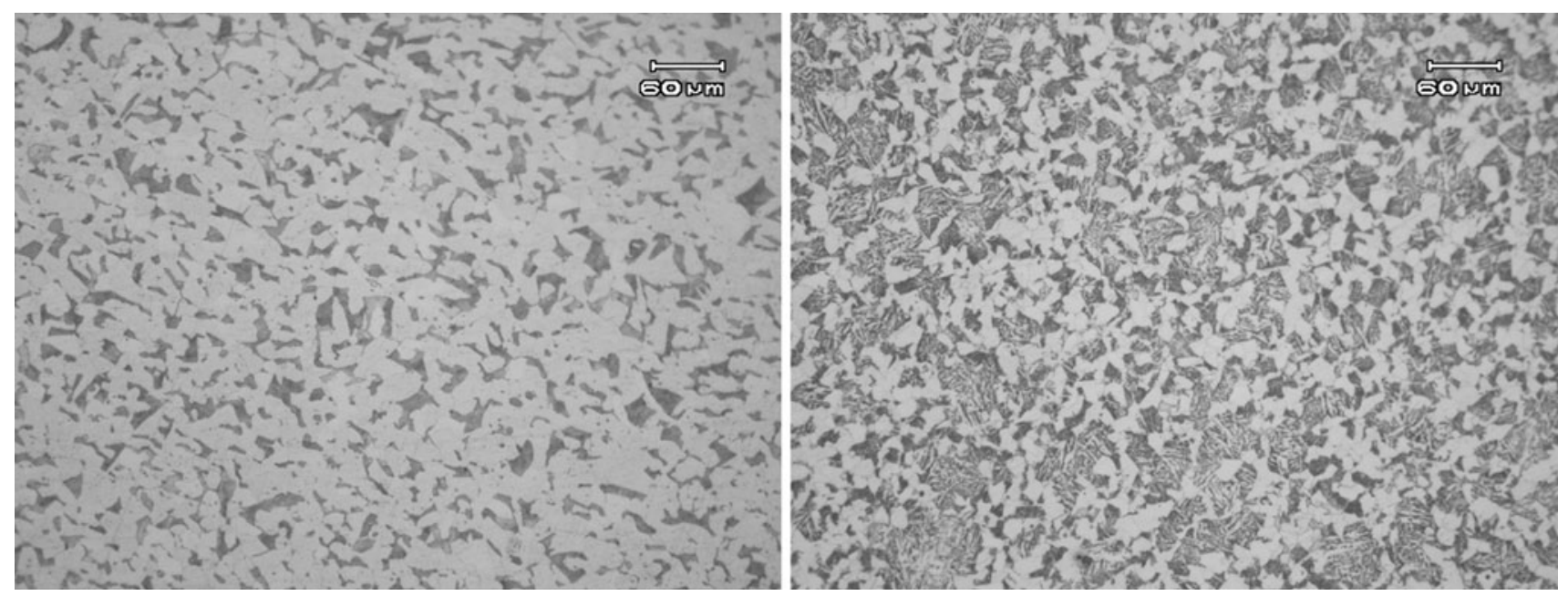

Fig. 4 On the left side, microstructure of as-received material for AISI 1020. On the right side, microstructure for as-received AISI 8620
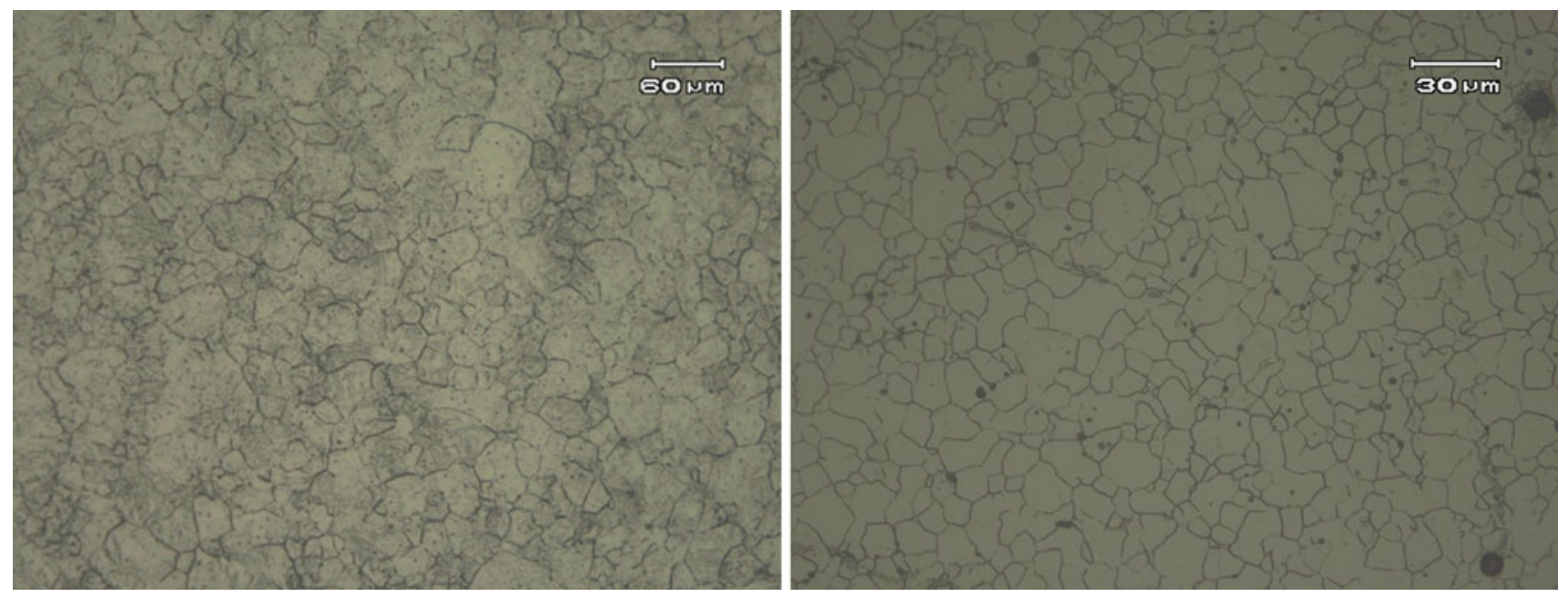

Fig. 5 On the left side, microstructure showing the prior austenite grain size for the as-received AISI 1020 steel. On the right side, the microstructure for the as-received AISI 8620 steel

Table 2 Table showing values of grain sizes found in as-received steel

\begin{tabular}{lcc}
\hline $\begin{array}{l}\text { Base } \\
\text { material }\end{array}$ & $\begin{array}{c}\text { Grain size, } \\
\boldsymbol{\mu m}\end{array}$ & $\begin{array}{c}\text { ASTM grain size } \\
\text { designationASTM E112 }\end{array}$ \\
\hline AISI 1020 & 23.6 & 8 \\
AISI 8620 & 10.6 & 10 \\
\hline
\end{tabular}

poured over the metallic part of each test sample. Grain size evaluation was performed using an optical microscope too.

Metallographic analyses were performed on the as-received steels and the micrographs are shown in Fig. 4. The microstructure of AISI 1020 is composed of ferrite and pearlite. The microstructure of AISI 8620 is also composed of ferrite and pearlite along with the acicular ferrite. In addition, prior austenite grain size analysis was performed, and the micrographs are shown in Fig. 5 and the results are summarized in Table 2.
After characterization of the as-received steels, test specimens were then carburized in a commercial Ipsen $\mathrm{T} 7$ furnace, quenched and tempered. The carburizing temperature was $920{ }^{\circ} \mathrm{C}$ using a propane-nitrogen-methanol atmosphere. (The ratio of nitrogen to methanol $\left(\mathrm{CH}_{3} \mathrm{OH}\right)$ is selected to yield approximately the same nitrogen-to-oxygen ratio as that of air-typically approximately 1.9 volumes of nitrogen for each volume of gaseous methanol.) The carbon potential was $0.9 \%$ for the AISI 1020 and AISI 8620 steels. After carburizing, the steel was cooled in air.

Conventional quenching for the AISI 8620 samples was performed after reaustenization at $870{ }^{\circ} \mathrm{C}$ in a furnace with controlled temperature and carbon potential of $1.0 \%$. ("Conventional" quenching refers to a petroleum oil quench.) The soaking time was $30 \mathrm{~min}$. After, heat treatment in a fast quenching oil with agitation was done (Houghtoquench $\mathrm{KB}$ at $60{ }^{\circ} \mathrm{C}$ ), the steel test specimen was tempered at $180{ }^{\circ} \mathrm{C}$ for $1 \mathrm{~h}$. For comparative purposes, a number of AISI 1020 steel test specimens were subjected to this same conventional quenching treatment. 


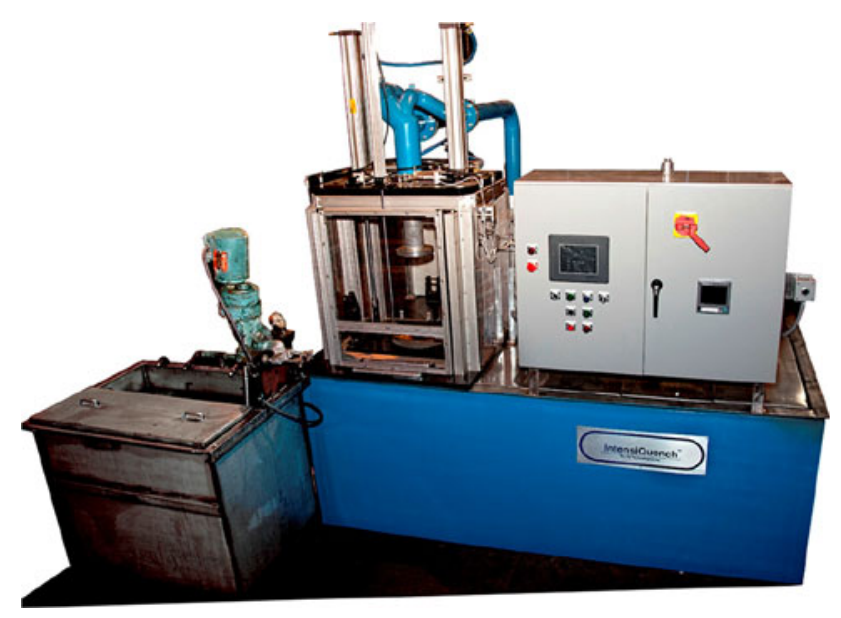

Fig. 6 Illustration of the intensive quenching equipment used by IQ Technologies in Akron, OH. A salt bath furnace is at the left of the illustration and the encased hydraulic intensive quenching "tube" is shown at the center

The remainder of the AISI 1020 steel test specimens were intensively quenched at IQ Technologies in Akron, Ohio. The AISI 1020 steel test specimens were austenitized at $870{ }^{\circ} \mathrm{C}$ for $30 \mathrm{~min}$ in a furnace with $1.0 \%$ carbon potential. After soaking, intensive quenching at an agitation rate of approximately $12 \mathrm{~m} / \mathrm{s}$ was performed by an IQ-3 process followed by tempering at $180{ }^{\circ} \mathrm{C}$ for $1 \mathrm{~h}$.

Although there are many ways by which intensive quenching may be performed, three of the most common processes are designated as IQ-1, IQ-2, and IQ-3 (Ref 5). In the IQ-1 process, intensive quenching is performed only in the martensitic transformation range. Steel is cooled from the austenitization temperature to the martensite start $\left(M_{\mathrm{S}}\right)$ temperature in a hot oil, high concentration of an aqueous salt solution, or an aqueous polymer quenchant at which time the steel is unloaded from the quench tank and then cooled under intensive jets of water which provide a very high cooling rate. The IQ-2 intensive quenching process is a three-stage process where cooling is performed without film-boiling until $50 \%$ martensite is formed in the superficial layers (case) at which time the intensive cooling process is interrupted and the steel is cooled in air until the temperature is uniform through the cross section and selftempering of the newly formed martensite occurs. Finally, intensive quenching is continued until the martensite transformation is completed. The IQ-3 process, which was used for this study, is conducted in a manner that eliminates both film boiling and nucleate boiling. Cooling only occurs by convection. This is accomplished by using powerful jets or streams of water to lower the surface temperature of the steel almost immediately to the temperature of the quenchant to create maximum thermal gradients between the surface and the core. The IQ-3 cooling process is performed until the maximum surface compressive stresses are formed which is the optimal condition.

The intensive quenching equipment used for this study is shown in Fig. 6. In this case, the test specimens and a tubular enclosure were heated in a salt bath furnace and then transferred to the hydraulically activated cell shown at the center. When the test specimen and tube (in which the quenchant flows) are transferred to the quenching chamber, the chamber closes hydraulically when the water flow is activated for the intensive quenching process. The flow rate for an IQ-3 process is sufficient

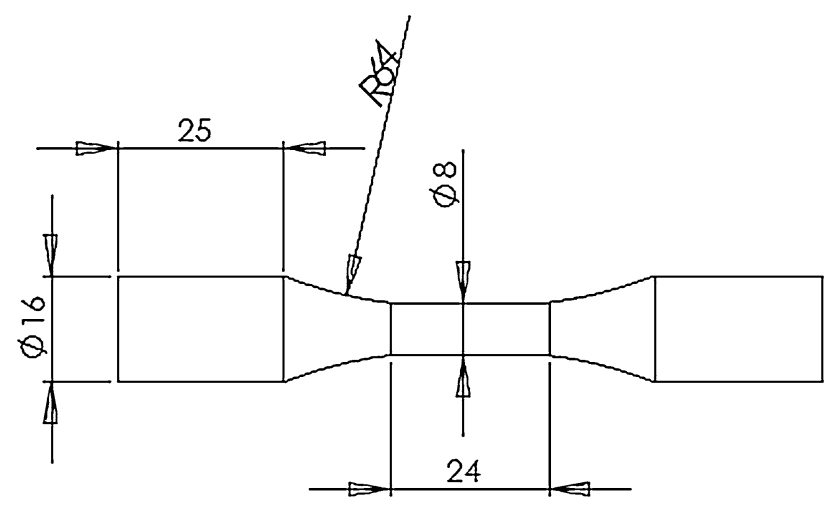

Fig. 7 Design of the test specimen for tensile and fatigue tests. Dimensions in millimeters

Table 3 Grain sizes of conventionally and intensively quenched carburized AISI 1020 and intensively quenched carburized AISI 8620

\begin{tabular}{lcc}
\hline Steel test specimen & $\begin{array}{c}\text { Grain size, } \\
\boldsymbol{\mu m}\end{array}$ & $\begin{array}{c}\text { Grain size } \\
\text { by ASTM E112 }\end{array}$ \\
\hline Intensively quenched AISI 1020 & 40.4 & 6.5 \\
Conventionally quenched AISI 1020 & 39.5 & 6.5 \\
Conventionally quenched AISI 8620 & 13.4 & 9.5 \\
\hline
\end{tabular}

to eliminate both film boiling and nucleate boiling on the surface of the test specimen, and uniform convective cooling results.

Metallography was performed in test specimens, as also reported previously. An Instron Tukon 2100 automatic microhardness tester was used for obtaining Vickers microhardness profiles by utilizing a $0.2-\mathrm{mm}$ indentation spacing from each other always beginning at $0.2 \mathrm{~mm}$ from the surface. The load was 300 gf. In order to define the carburized layer size, the preferred hardness was fixed as 550 Vickers. To obtain the hardness profiles, the ABNT NBR NM ISO 6507-3-2008 standard was followed.

Tensile tests were performed according to ASTM E8/E8M-11 (Ref 7). Three test specimens were tested, with the geometry schematically illustrated in Fig. 7. One specimen was used for intensive quenching of carburized AISI 1020, one for conventional quenching of carburized AISI 1020, and one for conventionally quenched carburized AISI 8620 steel. In order to perform the tests, a MTS Model 858 servohydraulic testing machine was used with a maximum load of $25 \mathrm{kN}$.

Fatigue testing was performed according to ASTM E466-07 (Ref 8). The test specimens shown in Fig. 7 were ground to remove possible machining marks and were axially tested. The same equipment utilized for tensile tests was used for fatigue tests. The frequency used was $20 \mathrm{~Hz}$ by counting with a sinusoidal wave. The $R$ value was 0.1 and the run out was taken at 2 million cycles.

Fractography was performed on the fractured test specimens after samples were fatigue tested. A low magnification Olympus SZ4045 TR CTV with digital image acquisition was used. In addition, a Shimadzu SSX-550 Superscan electron scanning microscope was used to observe the different failure micromechanisms. 


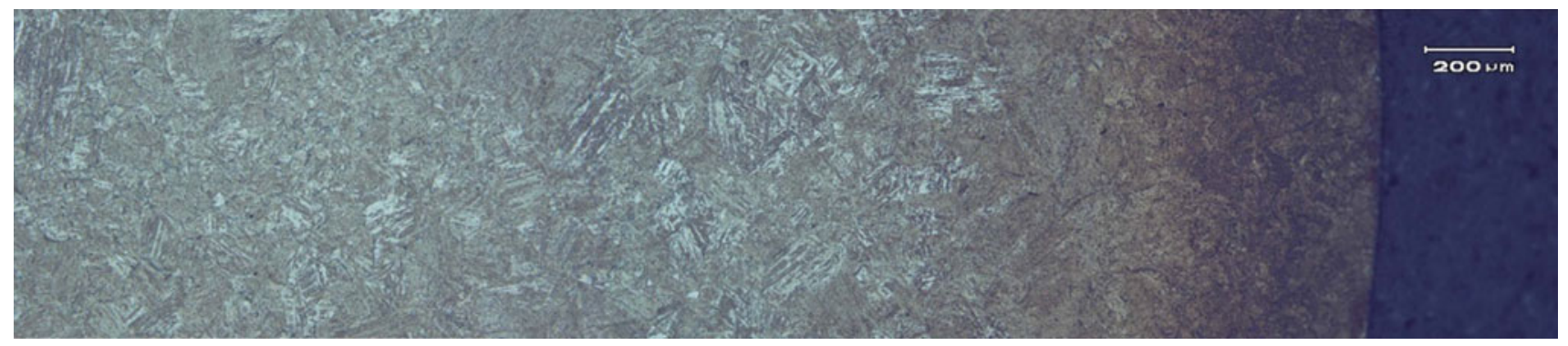

Fig. 8 Microstructural landscape of the carburized and intensively quenched AISI 1020 samples. Magnification $\times 100$

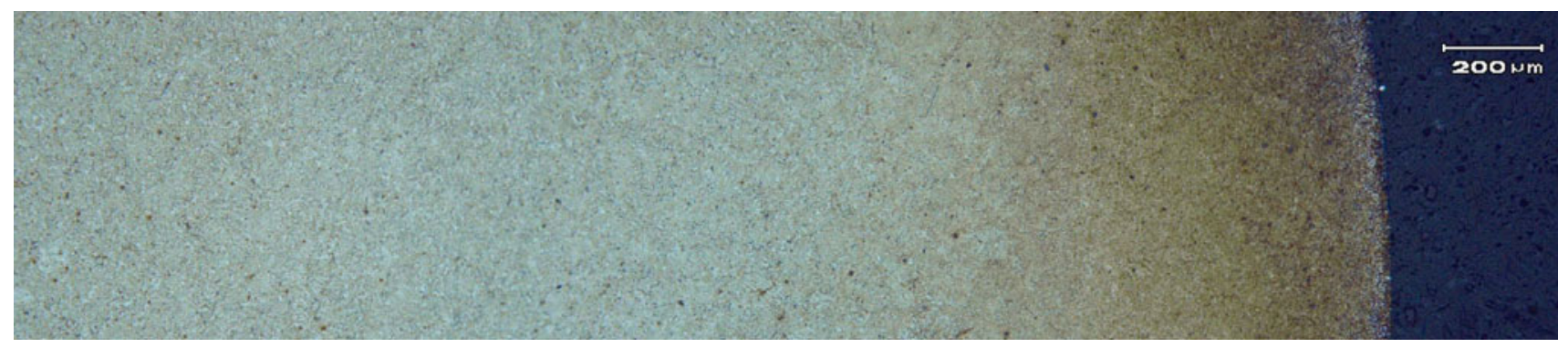

Fig. 9 Microstructural landscape of the carburized and conventionally quenched AISI 8620 samples. Magnification $\times 100$

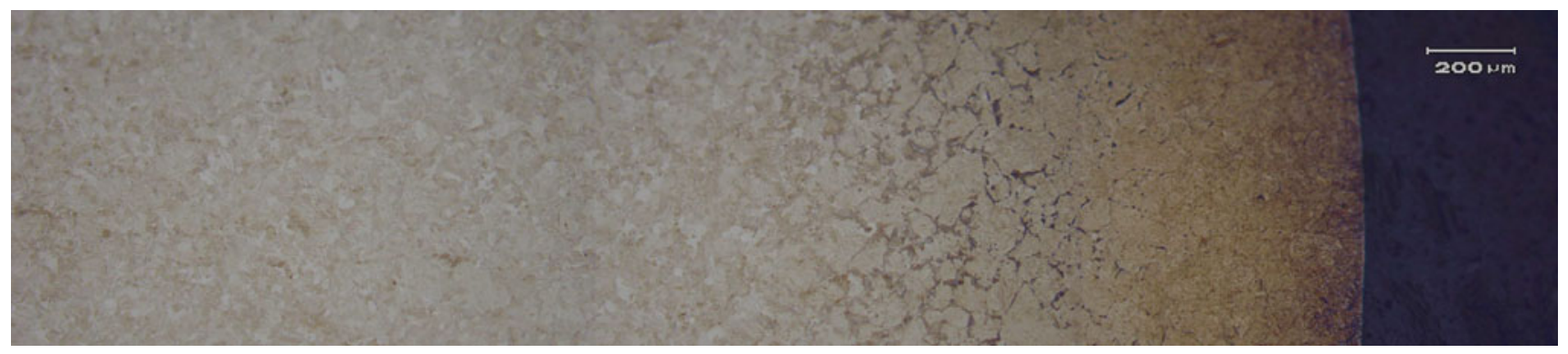

Fig. 10 Microstructural landscape of the carburized and conventionally quenched AISI 1020 samples. Magnification $\times 100$

\section{Results and Discussion}

The composition of both steels, AISI 1020 and AISI 8620, were within allowed specification limits as shown in Table 1. Grain size is influenced by the presence of aluminum together with nitrogen. The AISI 8620 steel contained $0.03 \%$ of aluminum which was ten times greater than the amount contained in AISI 1020 steel.

Optical microscopy showed that there was no internal oxidation or were there observed any microcracks within the carburized case. It is reported that if the silicon content is greater than $0.09 \%$, there is increased potential for the formation of internal oxidation (Ref 9). However, this was not observed.

Table 3 summarizes the grain sizes obtained for the three carburized steel test specimens used for this study. The ASTM grain sizes for carburized AISI 1020, whether conventionally or intensively quenched, were 6.5. The carburized low-alloy AISI 8620 steel yielded a smaller grain size than the carburized AISI 1020 steel (9.5 versus 6.5 ASTM). Comparison of the as-received steels (Table 1) with carburized steels (Table 2) showed that the ASTM grain size for AISI 8620 was essentially the same both before and after carburizing and conventionally quenching (ASTM 10 and 9.5, respectively). However, there was a significant difference in ASTM grain sizes observed before and after carburizing and quenching, whether conventionally or intensively quenching of ASTM 1020. The as-received steel ASTM grain size was 8 (Table 1) and 6.5 after carburizing (Table 2).

Parrish reported that the presence of nickel and molybdenum helps in preserving the grain size during austenitization at relatively high temperatures (Ref 9). Moreover, chemical analysis of the two steels showed that the AISI 8620 contained $0.03 \%$ of aluminum. Aluminum reacts with nitrogen forming a second phase of aluminum nitride particles. This reaction was established by plotting the solubility curves shown in Fig. 2. The difference in the grain sizes shown in Table 3 is substantial and can lead to a large difference in mechanical properties. The average grain size of the carburized and quenched AISI 1020 steel is three times greater than the grain size of the carburized and conventionally quenched AISI 8620 test specimens.

Figures 8, 9, and 10 show the microstructures obtained for the different carburized test specimens. A high-carbon martensitic microstructure is present in the near-surface carburized 


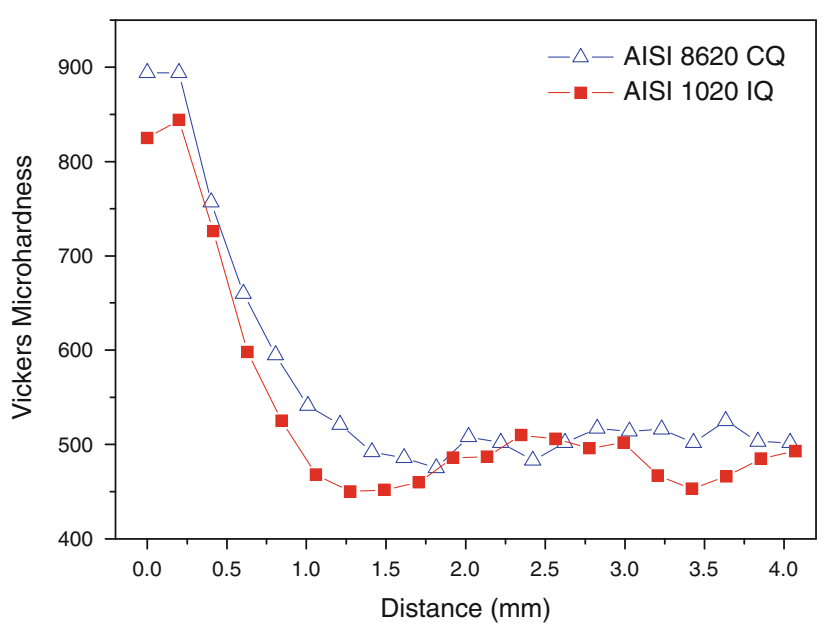

Fig. 11 Microhardness profiles for conventionally quenched (CQ) AISI 8620 (open triangle) and intensively quenched (IQ) AISI 1020 (filled square)

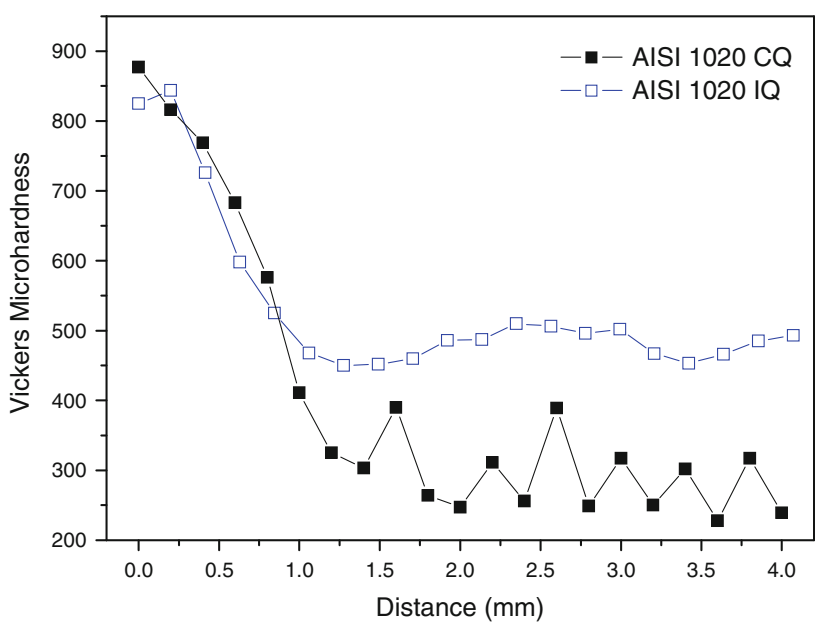

Fig. 12 Microhardness profiles for conventionally quenched (CQ) AISI 1020 (filled square) and intensively quenched (IQ) AISI 1020 (open square)

layer. The microstructure varies through the carburized case to the core. There is a transition zone between the carburized layer and the core. The conventionally quenched carburized AISI 8620 (Fig. 9) and the intensively quenched carburized AISI 1020 (Fig. 8) test specimens contain martensite as the primary microstructure only varying from a high-carbon martensite in the carburized case to a low-carbon martensite at the core. However, the conventionally quenched AISI 1020 specimens (Fig. 10) exhibit a high-carbon superficial martensitic structure, and as the core region is approached, there is a transition region with a mixed microstructure of martensite, bainite, pearlite, and ferrite. At the core, the microstructure is a mixture of low carbon martensite and acicular ferrite.

Figure 11 shows the microhardness profiles of the carburized and conventionally quenched AISI 8620 and the carburized and intensively quenched AISI 1020 steels. The case depth, conventionally defined as the depth to a hardness of $550 \mathrm{HV}$ is between 0.7 and $0.9 \mathrm{~mm}$ for both carburized steel grades. The superficial hardness is approximately 850 $\mathrm{HV}$, and the core hardness is approximately $450 \mathrm{HV}$. The

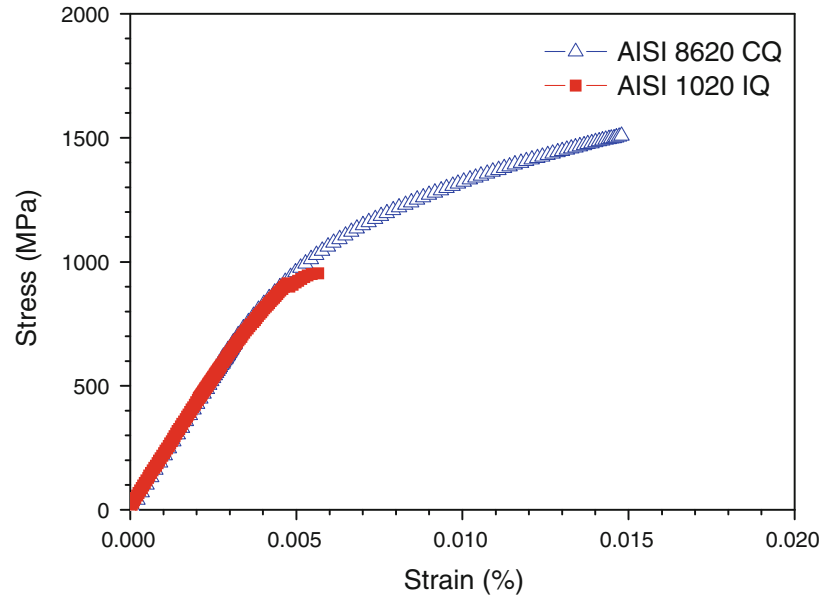

Fig. 13 Tensile test for conventionally quenched (CQ) AISI 8620 steel (open triangle) and intensively quenched (IQ) AISI 1020 steel (filled square)

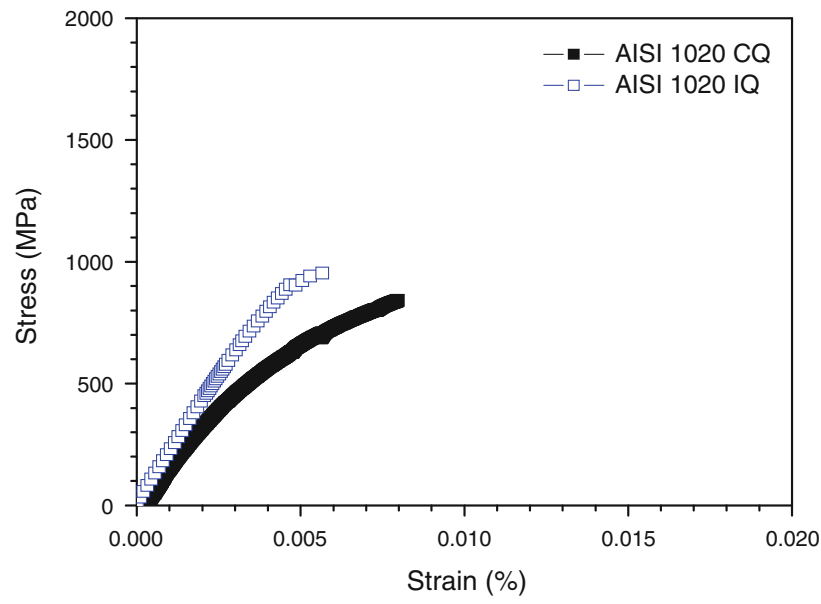

Fig. 14 Tensile tests for conventionally quenched (CQ) AISI 1020 (filled square) and intensively quenched (IQ) AISI 1020 (open square)

carburized carbon steel AISI 1020 which was subjected to intensive quenching exhibited nearly the same hardness profile as the low-alloy AISI 8620 steel test specimens subjected to conventional quenching. The use of intensive quenching would appear to allow for the replacement of low alloy steel with a less expensive carbon steel because the heat transfer is sufficiently intense to attain the maximum hardness. This is consistent with observations made earlier by Kimura (Ref 10).

In Fig. 12, the Vickers microhardness profiles are shown for the carburized and conventionally quenched AISI 1020 steel and the carburized and intensively quenched AISI 1020 steel. The carburized cases do not exhibit large differences. However, with intensive quenching, there is the preservation of martensite throughout the core region. The depth of the effective carburized layer is between 0.7 and $0.9 \mathrm{~mm}$ for both samples. There is an oscillation of hardness values at the core of the conventionally quenched carburized AISI 1020 test specimen. This may be due to the existence of regions of martensite and regions of ferrite. 


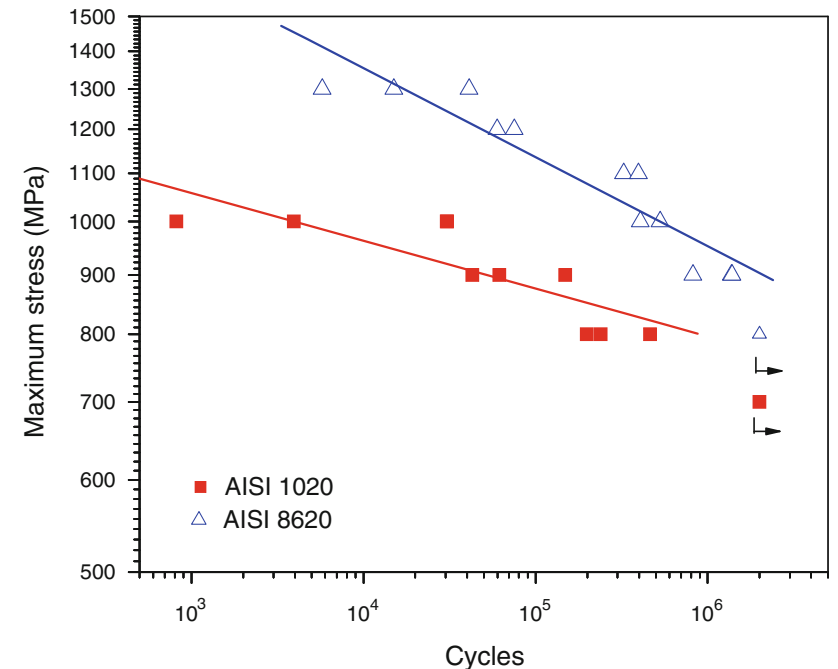

Fig. 15 Fatigue tests for the and intensively quenched AISI 1020 (filled square) and conventionally quenched AISI 8620 (open triangle) steels

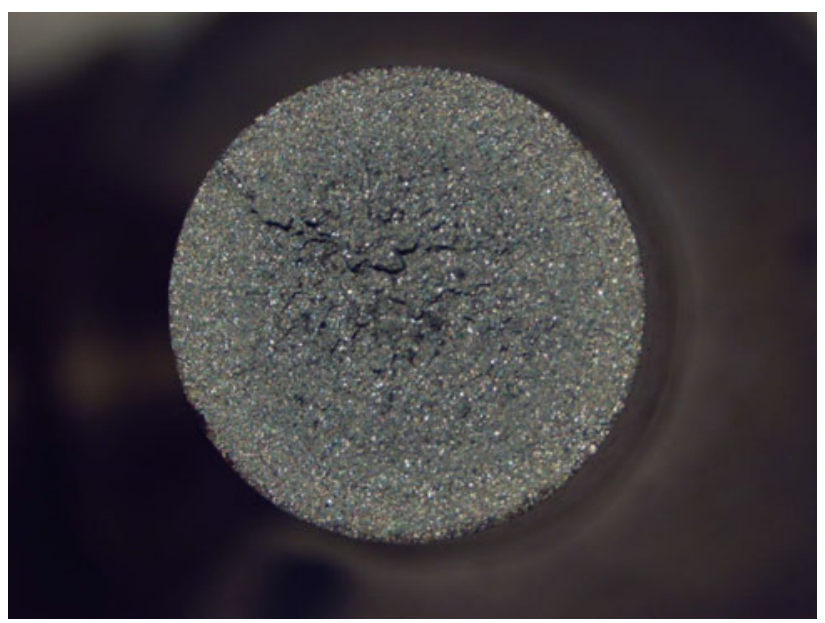

Fig. 16 Macroscopic view of the fracture in the sample 10 of the AISI 8620 steel

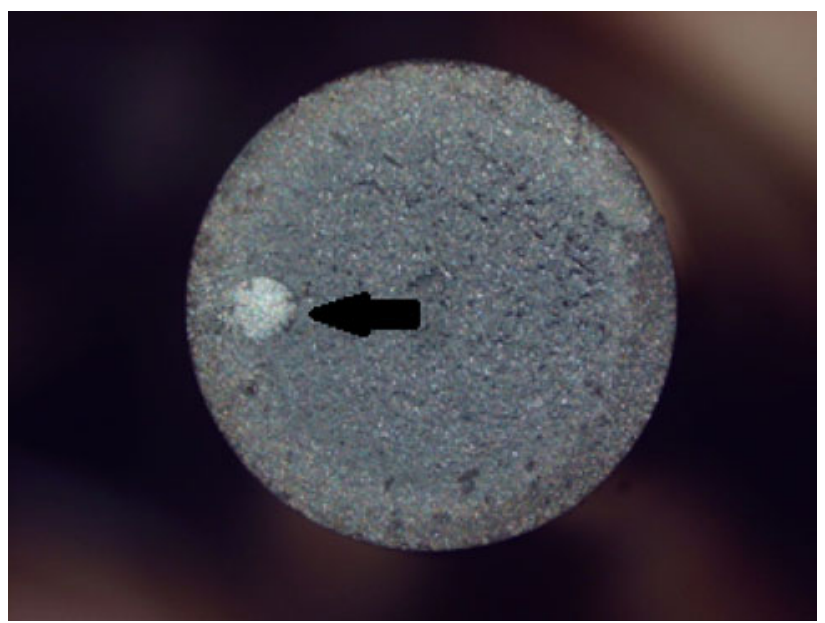

Fig. 17 Macroscopic view of the fracture in the sample 5 of the AISI 8620 steel

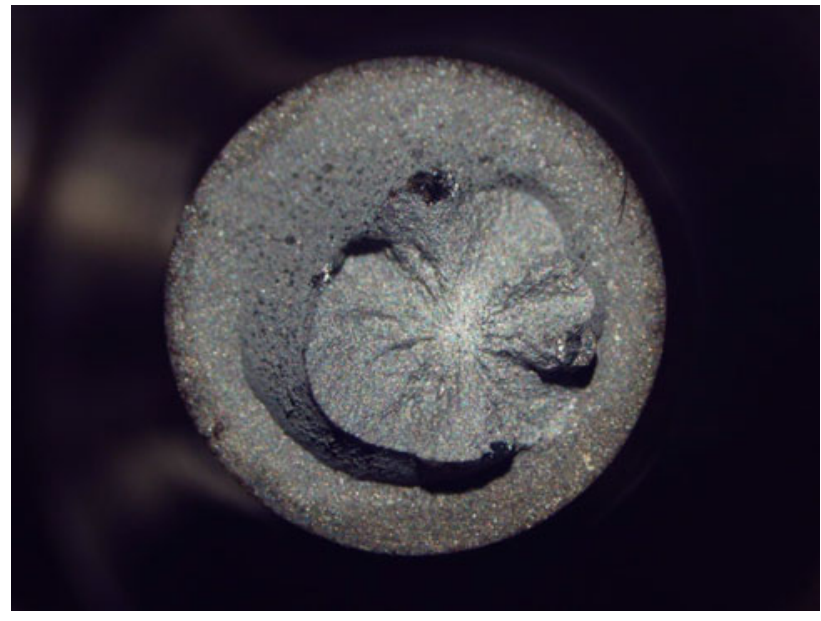

Fig. 18 Macroscopic view of the fracture in the sample 2 of the AISI 8620 steel

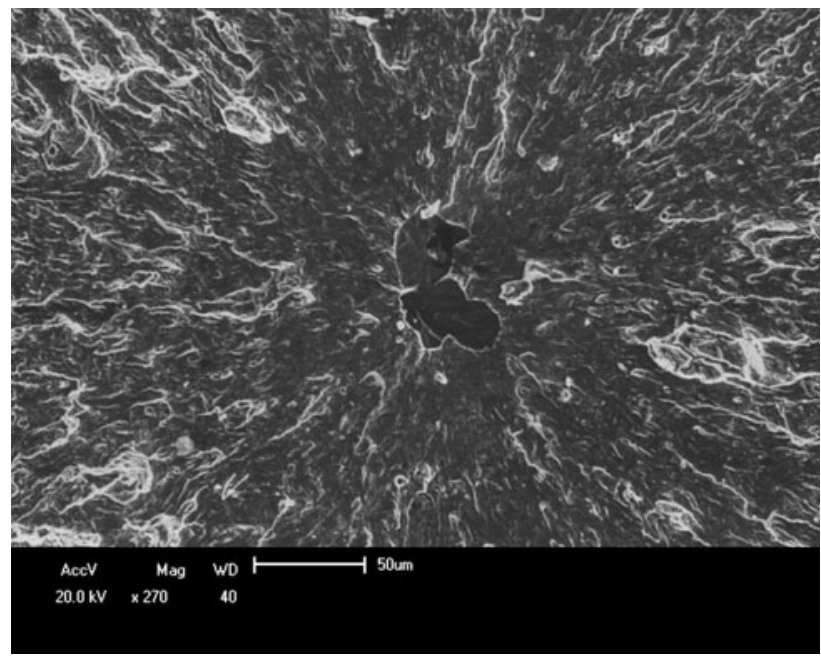

Fig. 19 Subsuperficial origin of the failure in sample 2 of AISI 8620 steel

Tensile test results are shown in Fig. 13. A comparison of conventionally quenched carburized AISI 8620 and intensively quenched carburized AISI 1020 showed that the AISI 8620 steel exhibited superior mechanical resistance compared with AISI 1020. The rupture stress of the AISI 1020 sample was $954 \mathrm{MPa}$, while the rupture stress of the AISI 8620 steel is $1510 \mathrm{MPa}$. From the literature, it is expected that a steel that is intensively quenched should exhibit superior tensile strength to a steel that was conventionally quenched (Ref 2, 4, 11-13) because intensive quenching produces "superhardening" (Ref 14, 15). However, as previously reported, the grain size may counterbalance this effect because of the more refined structure exhibited by the carburized AISI 8620 .

In order to compare the effects of different quenching processes, additional tensile tests were performed. Carburized AISI 1020 steel after intensive quenching yielded better mechanical resistance than the carburized AISI 1020 steel after conventional quenching, as seen in Fig. 14. However, the intensively quenched AISI 1020 tensile test specimen yielded a superior toughness compared with the conventionally quenched test specimen. This result confirms that intensive quenching 

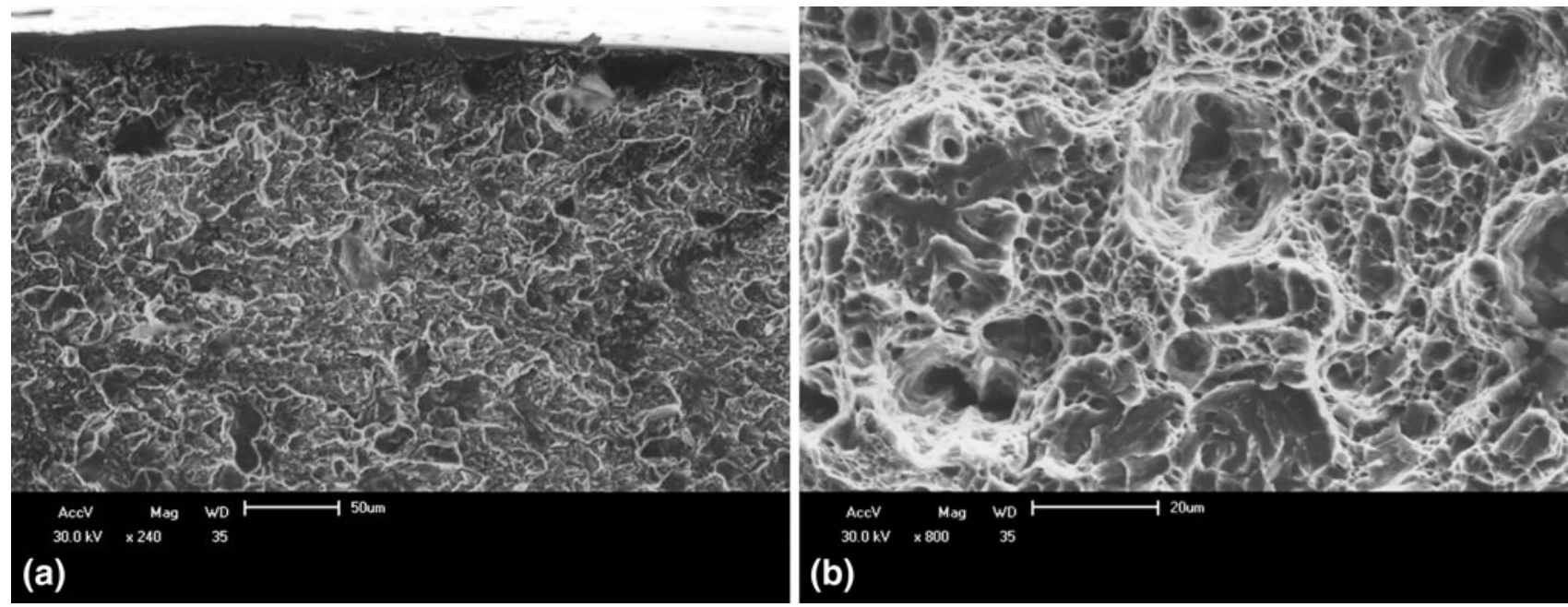

Fig. 20 Microfractographic characteristic of the samples of an AISI 8620 steel. (a) Transgranular micromechanism at the carburized layer region. (b) Dimples at the core of the sample

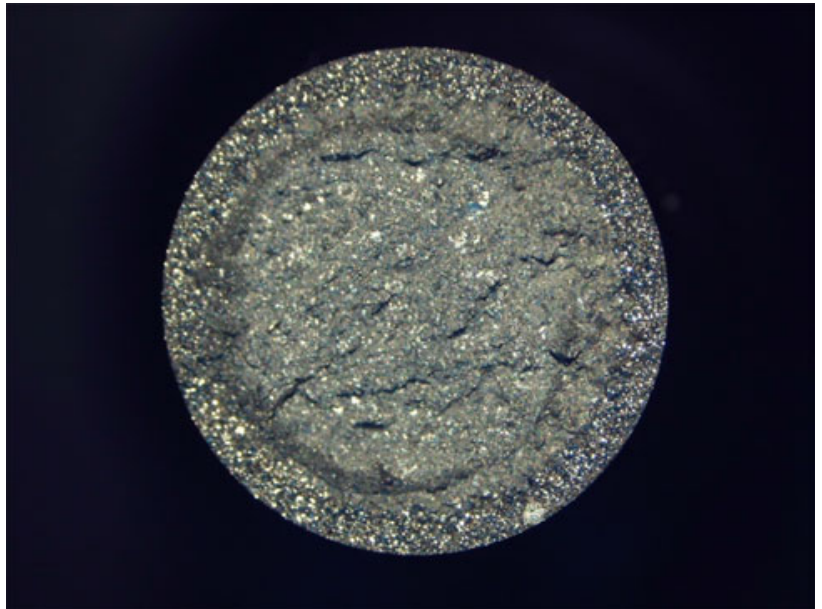

Fig. 21 Typical fractography of AISI 1020 steel, sample 3

produces better mechanical resistance relative to conventional quenching.

Using the Wohler curves shown in Fig. 15 as reference, it was possible to verify that the conventionally quenched carburized AISI 8620 yielded performance relatively superior to the intensively quenched carburized AISI 1020 steel. This is attributed to the large difference in grain size between the two types of steel which counters any potential advantage that may be afforded by intensive quenching, and this would be expected to result in better mechanical resistance and consequently better fatigue resistance. Moreover, it is assumed that any additional compressive residual stresses from intensive quenching would not be realized because of the non-optimal low diameter which would not be expected to yield the optimum hardened case depth after intensive quenching.

The surfaces of some of the fractured samples were inspected using low magnification. Macroscopically, two regions were distinct in all samples: an external layer that represents the fractured region in the carburized layer; and a central region, at the core, which exhibits a rougher fractured surface. The carburized AISI 8620 samples exhibited a more

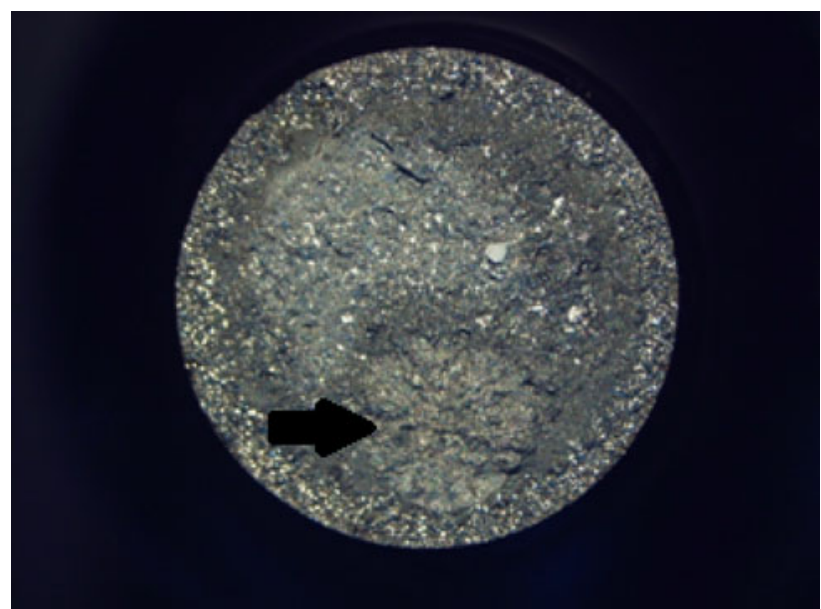

Fig. 22 Fractography with subsuperficial initiation referred to the AISI 1020 steel, sample 2

refined fracture characteristic compared with the carburized AISI 1020 samples because of the smaller grain size.

For the carburized 8620 steel, test specimen numbers 8,10 , and 11 did not exhibit a primary region of crack origin as seen in Fig. 16. Compared with other samples, these three fractured with fewer cycles. As the cycle number is increased, the appearance of the fracture possesses a small subsurface circle, which is referred to as the "crack origin." This type of fracture is seen in Fig. 17 and is related to samples that passed through a medium number of cycles.

However, test specimens 2, 4, and 12 correspond to highcycle testing. Figure 18 shows that the fracture in the subsuperficial region increases noticeably in size. These facts are in accordance with those reported by Reguly (Ref 16). These failures of medium and high cycles probably originate because of the presence of inclusions. Yin and Fatemi (Ref 17) also indicated that the high-cycle regime and low stress failures have their origin in the subsuperficial carburized layer.

In the microfractographies obtained by SEM, as seen in Fig. 19, the sub-superficial origin of failure can be observed which contains a cavity that probably indicates the presence of 

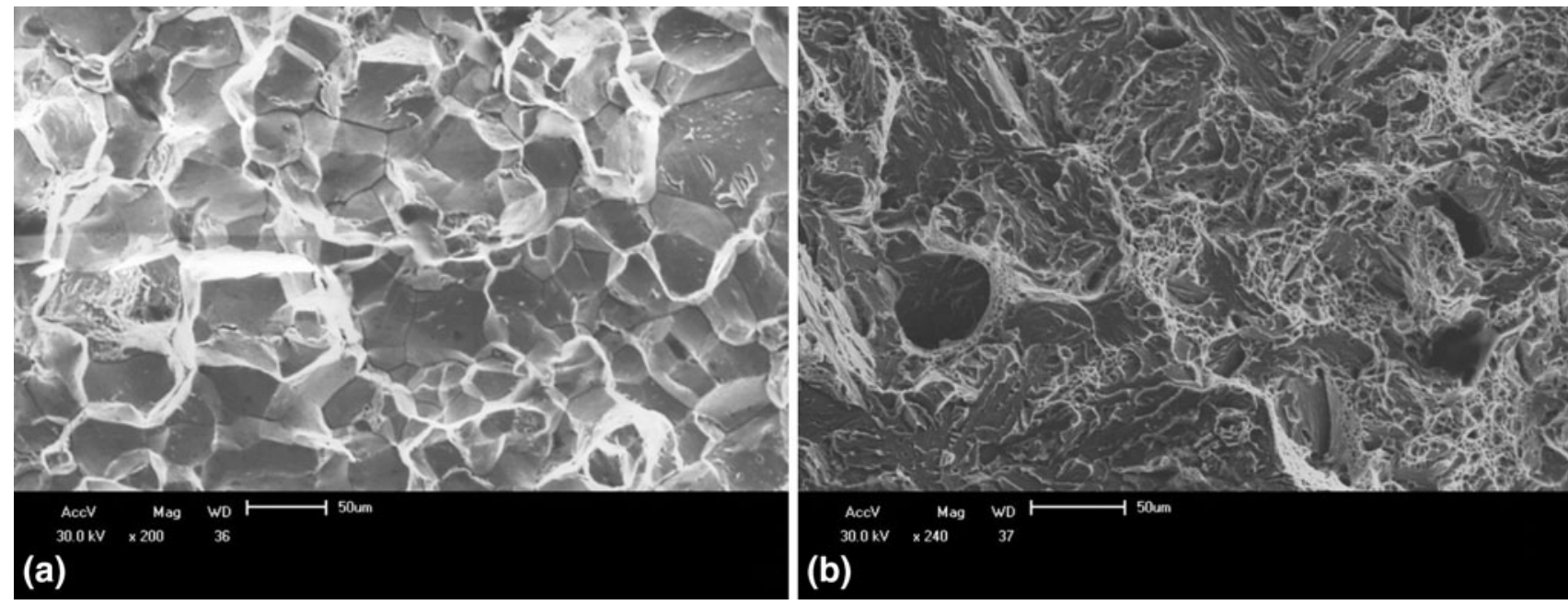

Fig. 23 (a) Micrography of the carburized layer of AISI 1020 steel, sample 10. (b) Microfractography of the core region of AISI 1020, sample 2

an inclusion (Test Specimen 2). All samples of the carburized AISI 8620 steel exhibited a transgranular characteristic (Fig. 20a). In the central region, extensive dimples in all samples were observed (Fig. 20b).

For the carburized AISI 1020 steel samples, a larger grain size is visible at the fracture, as well as an irregular fractographic surface, as seen in Fig. 21. This shows a clear region of fatigue initiation only for Test Specimen 2 which can be seen in Fig. 22. In this case, it is possible to observe the crack origin. In all other samples, there were no failure initiation regions.

In all the samples, a carburized layer with only intergranular characteristics was seen as illustrated in Fig. 23(a). The core region exhibited a mixture of dimples with cleavage as shown in Fig. 23(b).

\section{Conclusions}

Intensive quenching provides a substantial potential to utilize less expensive steel materials such as carburized lowcarbon AISI 1020 steel. However, the study reported here indicates that such steels must be killed by the addition of appropriate elements. Non-killed steels yield excessively large grain sizes that severely limits their use.

Plain carbon steels typically do not contain $\mathrm{Al}$ and $\mathrm{Ti}$ elemental additions and to achieve optimal results, a grain size of at least 6-8 is required. In this case, intensive quenching improved all the characteristics compared with conventional quenching of carburized AISI 1020 steel. However, these results also showed that intensive quenching of non-killed carbon steels, such as AISI 1020, cannot effectively compete with a killed AISI 8620 alloy steel which exhibits a much finer grain structure because of the presence of $\mathrm{Al}$ and alloying elements $\mathrm{Ni}$ and Mo) (Ref 18, 19).

To substitute a carburized alloy steel with a carburized plaincarbon steel, two main conditions should be satisfied:

1. High compressive residual stresses at the surface of steel parts should be formed.

2. Material at the core of steel parts should exhibit fine microstructure (grain size 10-11). According to RU Patent \#
2158320 , fine microstructure can be achieved if steel contains aluminum $(0.03-0.1 \%)$ and titanium $(0.06-0.12 \%)$ (Ref 20). Both factors, high compressive residual stresses and very fine microstructure, may compensate for the use of decreasing alloying elements in the steel.

\section{Acknowledgments}

The authors express their sincere appreciation to Engineer Jorge Braz and Forjas Taurus for their assistance with performing the heat treatment and conventional quenching of the test specimens used in this study, and all of the students, technicians, and professors that were involved with this research. Special acknowledgements are due to the Brazilian agencies CAPES and CNpQ for funding this research.

\section{References}

1. ASM Committee on Gas Carburizing, Carburizing and Carbonitriding, American Society for Metals, Metals Park, OH, 1977

2. N.I. Kobasko, M.A. Aronov, J.A. Powell, L.C.F. Canale, and G. Totten, Fundamentos Metalúrgicos e Levantamento dos Processos de Têmpera Intensiva, $1 \overline{1}$ Congresso SAE, São Paulo, 2002

3. N.I. Kobasko, M.A. Aronov, J.A. Powell, L.C.F. Canale, and G. Totten, Metallurgy of the Intensive Quenching Process and Implications with Respect to Steel Properties, Anais do $5 \overline{8}$ Congresso Anual da ABM, Rio de Janeiro, 2003, p 3362-3380

4. N.I. Kobasko, M.A. Aronov, J.A. Powell, L.C.F. Canale, and G. Totten, Intensive Quenching Process Classification and Applications, Heat Treat. Met., 2004, 31, p 51-58

5. N.I. Kobasko, M.A. Aronov, J. Powell, and G.E. Totten, Intensive Quenching Systems: Engineering and Design, ASTM International, Newburyport, 2010

6. ASTM E112-96, Standard Test Methods for Determining Average Grain Size, ASTM International, West Conshohocken, PA, 2004

7. E8/E8M-11, Standard Test Methods for Tension Testing of Metallic Materials, ASTM International, West Conshohocken, PA

8. ASTM E466-07, Standard Practice for Conducting Force Controlled Constant Amplitude Axial Fatigue Tests of Metallic Materials, ASTM International, West Conshohocken, PA

9. G. Parrish, Carburizing: Microstructures and Properties, ASM International, Metals Park, OH, 1999 
10. R. Kimura, Y. Sekiya, T. Naito, N.I. Kobasko, M.A. Aronov, and J.A. Powell, Intensive Quenching Method, J. Jpn. Soc. Heat Treat., 2009, 49(1), p 1-7

11. N.I. Kobasko, M.A. Aronov, J.A. Powell, L.C.F. Canale, and G. Totten, Improved Production of Automotive Parts by Intensive Quench Processing, La Metallurgia Italiana, 2006, 1, p 13-22

12. Anon, "IntensiQuench Process Theory and Applications", 2002, Brochure available from: IQ Technologies, Inc., Akron, OH, http:// www.intensivequench.com/

13. N.I. Kobasko, M.A. Aronov, and J.A. Powell, Application of Intensive Quenching Methods for Steel Parts, Proceedings of 20th ASM Heat Treating Conference (St. Louse, MO), 2000

14. N.I. Kobasko, Steel Super-Strengthening Phenomenon, J. ASTM Int., 2005, 2(2), p 1-13

15. N.I. Kobasko, Steel Super-Strengthening Phenomenon Part I, Int. J. Mater. Prod. Technol., 2005, 24(1-4), p 361-374
16. A. Reguly, Iniciação e Propagação de Trincas por Fadiga em Aços Cementados e em Aços Temperados por Indução. Dissertação de Mestrado, PPGE3M - UFRGS, Porto Alegre, 1994

17. F. Yin and A. Fatemi, Fatigue Behaviour and Life Predictions of CaseHardened Steels, Fatigue Fract. Eng. Mater. Struct., 2009, 32, p 197-214

18. K. Ouchakov Boris and Z. Shepelyakovskii Konstantin, New Steels and Methods for Induction Hardening of Bearing Rings and Rollers, Bearing Steels: Into the 21st Century, ASTM STP 1327, 1998, p 307320

19. N. Kobasko, Limited-Hardenability Steels and New Heat Treating Technologies, Material Science \& Technology 2007 Conference and Exhibition (MS\&T07), Sept. 16-20, COBO Center, Detroit, MI, 2007, p $471-480$

20. Russian Patent No. 2158320, Construction Steel of Low Hardenability, Application No. 99125102, Filed on Nov. 29, 1999 